Louisiana State University

LSU Digital Commons

$1-1-1993$

\title{
Differential susceptibility of guanine nucleotide-binding proteins to pertussis toxin-catalyzed ADP-ribosylation in brain membranes of two congeneric marine fishes
}

\author{
T. F. Murray \\ Louisiana State University \\ J. F. Siebenaller \\ Louisiana State University
}

Follow this and additional works at: https://digitalcommons.Isu.edu/biosci_pubs

\section{Recommended Citation}

Murray, T., \& Siebenaller, J. (1993). Differential susceptibility of guanine nucleotide-binding proteins to pertussis toxin-catalyzed ADP-ribosylation in brain membranes of two congeneric marine fishes.

Biological Bulletin, 185(3), 346-354. https://doi.org/10.2307/1542475

This Article is brought to you for free and open access by the Department of Biological Sciences at LSU Digital Commons. It has been accepted for inclusion in Faculty Publications by an authorized administrator of LSU Digital Commons. For more information, please contact ir@lsu.edu. 
Reference: Biol. Bull. 185: 346-354. (December, 1993)

\title{
Differential Susceptibility of Guanine Nucleotide- binding Proteins to Pertussis Toxin-catalyzed ADP- ribosylation in Brain Membranes of Two Congeneric Marine Fishes
}

\author{
THOMAS F. MURRAY ${ }^{1}$ AND JOSEPH F. SIEBENALLER ${ }^{2, *}$ \\ ${ }^{1}$ College of Pharmacy, Oregon State University, Corvallis, Oregon 97331, and ${ }^{2}$ Department of \\ Zoology and Physiology, Louisiana State University, Baton Rouge, Louisiana 70803
}

\begin{abstract}
Pertussis toxin-catalyzed $\left[{ }^{32} \mathrm{P}\right]$ ADP-ribosylation was used to probe the guanine nucleotide binding regulatory proteins $G_{i}$ and $G_{0}$ in brain membranes from two scorpaenid fishes, Sebastolobus alascanus and S. altivelis. The membranes of the two species exhibit a differential sensitivity to $\left.{ }^{32} \mathrm{P}\right] \mathrm{ADP}$-ribosylation produced by a fixed concentration of pertussis toxin. The membranes from the deeper-living $S$. altivelis consistently incorporated more $\left.{ }^{32} \mathrm{P}\right] \mathrm{ADP}$ than the membranes from $S$. alascanus. Proteins of 39 and $41 \mathrm{kDa}$ are specifically labeled in both species, corresponding to the apparent molecular masses of the $\alpha$ subunits of $\mathrm{G}_{\mathrm{i}}$ and $\mathrm{G}_{0}$. At $5^{\circ} \mathrm{C}$ the ribosylation reaction is linear for at least $7 \mathrm{~h}$. The pertussis toxin concentration-response relationship was evaluated with concentrations of pertussis toxin from 0 to $100 \mathrm{ng} /$ $\mu \mathrm{l}$. The extent of $\left.{ }^{32} \mathrm{P}\right] \mathrm{ADP}$-ribosylation was quantified by autoradiography and computer-assisted image analysis. The $\mathrm{EC}_{50}$ values for pertussis toxin were similar for the two species, but the maximum level of $\left[{ }^{32}\right.$ P]ADP-ribosylation was significantly greater in $S$. altivelis brain membranes. Because the heterotrimeric holoprotein is the substrate for ribosylation, the modulatory effects of the guanyl nucleotides GDP and GTP $\gamma \mathrm{S}$ on the ribosylation were assessed. GDP increased [ $\left.{ }^{32} \mathrm{P}\right] A D P$-ribosylation of the $\alpha$ subunits in $S$. altivelis. Only the highest concentration tested $(1000 \mu M)$ increased $\left[{ }^{32} \mathrm{P}\right]$ ADP-ribosylation in $S$. alascanus brain membranes and only to a modest extent. Increasing concentrations of GTP $\gamma \mathrm{S}$ suppressed $\left[{ }^{32} \mathrm{P}\right] \mathrm{ADP}$-ribosylation in $S$. alascanus brain membranes,
\end{abstract}

Received 26 October 1992; accepted 30 September 1993.

* To whom reprint requests should be addressed. presumably by promoting dissociation of the holotrimer. GTP $\gamma$ S had much less of an effect on the $S$. altivelis brain membranes. These differences in the extent of ADP-ribosylation and the modulatory effects of guanyl nucleotides may reflect different coupling efficiencies of $G$ proteins and receptors. The expression of the $\alpha$ and $\beta$ subunits of $\mathrm{G}_{\mathrm{i}}$ and $\mathrm{G}_{\mathrm{o}}$ in the two Sebastolobus species, the deepsea morid teleost fish Antimora rostrata, and the rat were compared by Western immunoblotting of brain membranes with antipeptide antisera. Levels of $\mathrm{G}_{\mathrm{i} \alpha 3}$ were $63 \%$ higher in brain membranes of $S$. altivelis than those in $S$. alascanus. The levels of $\mathrm{G}_{\mathrm{i} \alpha 1}, \mathrm{G}_{\mathrm{i} \alpha 2}, \mathrm{G}_{\mathrm{o}}$ and $\beta_{36}$ were similar in the two species. Although the complement of $G$ proteins identified by the array of antisera used was similar in all the species, there appears to be additional diversity of $\alpha$ subunits in the teleost brain membranes. In fish, antiserum to $G_{o \alpha}$ reacted with an additional 41 to $42 \mathrm{kDa}$ protein that was not expressed in rat brain.

\section{Introduction}

The hydrostatic pressures characteristic of the deep sea exert profound effects on the physiology and biochemistry of organisms in this extensive habitat (Siebenaller, 1987, 1991; Siebenaller and Somero, 1989). Among the processes affected is guanine nucleotide binding protein (G protein)-coupled transmembrane signaling (Siebenaller $e t$ al., 1991; Siebenaller and Murray, 1993). In $A_{1}$ adenosine receptor-modulation of adenylyl cyclase in teleost brain membranes, pressure affects agonist efficacy (Siebenaller et al., 1991; Siebenaller and Murray, 1993), the coupling of the receptor to adenylyl cyclase (Siebenaller et al., 1991), and the enzymatic activities of components of the system, 
i.e., adenylyl cyclase activity (Siebenaller $e t$ al., 1991) and the high-affinity GTPase activity of $\alpha$ subunits of G proteins (Siebenaller and Murray, 1993).

G proteins couple a diverse superfamily of cell surface receptor proteins (estimated at up to 1000, e.g., Barinaga, 1991) to a variety of effector elements such as adenylyl cyclase, ion channels, and phospholipases (Birnbaumer et al., 1990). Because $G$ proteins are central to transmembrane signaling, physical factors, such as pressure, may be critical as selective forces influencing adaptation and shaping the functional characteristics of $\mathrm{G}$ proteins.

$G$ proteins are heterotrimers and the subunits are designated $\alpha, \beta$, and $\gamma$. The classes of $\mathrm{G}$ proteins are defined by the $\alpha$ subunit type (Gilman, 1987), and further diversity of the $\alpha$ subunits has been documented by molecular genetic techniques (e.g., Simon et al., 1991). The general features of the model of $G$ protein-coupled signaling are briefly described here (see Gilman, 1987, and Birnbaumer et al., 1990). Agonist-liganded receptors interact with $G$ proteins, promoting the binding of GTP to the guanine nucleotide binding site on the $\alpha$ subunit. GTP binding evokes a conformational change ( $\mathrm{Yi}$ et al., 1991), causing the protein to dissociate into $\alpha \cdot$ GTP and a $\beta \gamma$ dimer (Gilman, 1987; Birnbaumer et al., 1990; Boege et al., 1991). The activated $\alpha \cdot$ GTP complex and the $\beta \gamma$ dimer interact with the target enzyme (Gilman, 1987; Lefkowitz, 1992; Birnbaumer, 1992). Signaling is terminated by the hydrolysis of bound GTP to GDP by the intrinsic GTPase activity of the $\alpha$ subunit and the subsequent reassociation of the $\alpha$ and $\beta \gamma$ subunits.

The inhibitory $G$ protein $\left(G_{i}\right)$ plays a role in receptormediated inhibition of adenylyl cyclase, whereas $G_{o}$ is a common $G$ protein in brain membranes. These two classes of $\mathrm{G}$ proteins are specific substrates for mono-ADP-ribosylation by pertussis toxin (Katada and Ui, 1982; Gierschik, 1992). Pertussis toxin catalyzes the transfer of an ADP-ribose moiety from $\mathrm{NAD}^{+}$to a specific cysteine four residues from the carboxyterminus of the $\alpha$ subunit in the heterotrimer. ADP-ribosylation prevents the coupling of the modified $\mathrm{G}$ protein to its receptor and therefore a response to agonists (Gierschik, 1992). Because the heterotrimeric holoprotein is the substrate for ADP-ribosylation (Neer et al., 1984; Van Dop et al., 1984), pertussis toxin has been used to characterize the subunit aggregation state and the conformation of $\mathrm{G}$ proteins (e.g., Yi et al., 1991 ), as well as the interaction of receptors and $G$ proteins (e.g., van der Ploeg et al., 1992).

The $\alpha$ subunits of $G_{i}$ and $G_{0}$ serve as transduction elements in $A_{1}$ adenosine receptor transmembrane signaling (Linden, 1991). We have used pertussis toxin-catalyzed ADP-ribosylation to probe the $G_{i}$ and $G_{o}$ proteins of two Sebastolobus species in order to identify species differences that might be correlated with the differences in the pressure sensitivity of $A_{1}$ adenosine receptor-mediated inhibition of adenylyl cyclase (Siebenaller et al., 1991). These two scorpaenid fishes of the genus Sebastolobus have similar life histories, experience similar temperatures, but occur at different depths (Hubbs, 1926; Siebenaller and Somero, 1978). With these species, fine-scale adaptations to pressure have been delineated without the potentially confounding effects of other environmental variables or phylogenetic distance (e.g., Siebenaller, 1984a, b, 1987).

We observed previously that the extent of $\left[{ }^{32} \mathrm{P}\right]$ ADPribosylation produced by a fixed concentration of pertussis toxin is different in the two Sebastolobus species (Siebenaller and Murray, 1990; Siebenaller et al., 1991). Brain membranes from the deeper-living $S$. altivelis incorporate more [ $\left.{ }^{32} \mathrm{P}\right] A D P$ than $S$. alascanus membranes (Siebenaller et al., 1991). Our previous work (e.g., Murray and Siebenaller, 1987; Siebenaller and Murray, 1990; Siebenaller et al., 1991) suggested that the coupling of $G$ proteins to receptors would be different in species adapted to different pressure regimes; e.g., the two Sebastolobus species that experience different pressure regimes yet have brain membranes with identical phospholipid and fatty acid compositions (Siebenaller et al., 1991). A less tightly coupled and more flexible signaling complex may be required for optimal function in the more highly ordered membranes which result at the higher pressures experienced by the deeper-living $S$. altivelis (Siebenaller et al., 1991; see also Casadó et al., 1992; Shinitzky, 1984).

In the present study we have confirmed the difference in pertussis toxin-catalyzed incorporation of $\left.{ }^{32} \mathrm{P}\right] \mathrm{ADP}$ into the $\alpha$ subunits of $\mathrm{G}_{\mathrm{i}}$ and $\mathrm{G}_{\mathrm{o}}$ of the two Sebastolobus species. We have tested two possible reasons for this difference in $\left[{ }^{32} \mathrm{P}\right] \mathrm{ADP}$ ribosylation: that the G-proteins of the two species are differently suitable as substrates for ribosylation (i.e., that the ribosylation site of $S$. altivelis is more susceptible to pertussis toxin); or that the levels of the $G$ protein substrates in the two species are different. We have quantified the steady state levels and subtypes of $G_{i}$ and $G_{o} \alpha$ and $\beta$ subunits by Western immunoblot analyses as a measure of the differential expression of subunits in the two species. To examine and characterize the coupling of $G$ proteins to receptors in the two species, we have tested the effects of guanyl nucleotides on pertussis toxin-catalyzed ribosylation. We relate these data to differences in the coupling of the $A_{1}$ adenosine receptor to adenylyl cyclase in brain membranes of the two Sebastolobus species.

\section{Materials and Methods}

\section{Specimens}

Demersal adults of Sebastolobus (Scorpaenidae) were collected by otter trawl off the coast of Oregon at their typical depths of abundance on two cruises of the R/V Wecoma. S. alascanus adults are common between 180 
and $330 \mathrm{~m}$; the adults of $S$. altivelis are found between 550 and $1300 \mathrm{~m}$ (Miller and Lea, 1976). Demersal Antimora rostrata (Moridae) were collected at their typical depths of abundance, 850-2500 m (Haedrich and Merret, 1988), off the coast of Newfoundland, Canada, on a cruise of the R/V Gyre. Brain tissue was dissected, frozen in liquid nitrogen at sea, and transported to the laboratory where tissues were maintained at $-80^{\circ} \mathrm{C}$ until used.

Frozen rat brains were obtained from Pel-Freez (Rogers, Arkansas) and forebrains were dissected following thawing of the whole brain.

\section{Preparation of brain membranes}

Membranes were homogenized with a Dounce (Pestle A) in 40 volumes of $50 \mathrm{mM}$ Tris- $\mathrm{HCl}, \mathrm{pH} 7.6$ at $5^{\circ} \mathrm{C}$, containing $0.3 \mathrm{mg} / \mathrm{ml}$ soybean trypsin inhibitor and 3.4 $\mathrm{mg} / \mathrm{ml}$ bacitracin. The homogenate was centrifuged at $27,000 \times g\left(0\right.$ to $\left.4^{\circ} \mathrm{C}\right)$ for $10 \mathrm{~min}$. The pellet was resuspended in 40 volumes of buffer and recentrifuged. The pellet was resuspended in 40 volumes of buffer and used in the ribosylation assays.

The protein concentration was determined prior to experimentation to permit adjustment of the samples to equivalent protein concentrations. Protein was determined by the method of Lowry et al. (1951) following solubilization of the samples in $0.5 \mathrm{M} \mathrm{NaOH}$. Bovine serum albumin (Sigma) was used as the standard.

\section{$\left[{ }^{32} P\right] A D P$ ribosylation}

Pertussis toxin-catalyzed $\left[{ }^{32} \mathrm{P}\right]$ ADP ribosylation of $\alpha$ subunits of $G_{i}$ and $G_{0}$ followed the procedures described in Siebenaller and Murray (1990). Pertussis toxin was activated in $100 \mathrm{~m} M$ Tris- $\mathrm{HCl}, \mathrm{pH} 8.0$ with $50 \mathrm{~m} M$ dithiothreitol for $1 \mathrm{~h}$ at room tempcrature. The $100 \mu \mathrm{l}$ incubation mixture routinely contained $100 \mathrm{mM}$ Tris- $\mathrm{HCl}$, $\mathrm{pH} 7.6$ at the incubation temperature of $5^{\circ} \mathrm{C}, 25 \mathrm{mM}$ dithiothreitol, $2 \mathrm{mM}$ ATP, $2 \mu \mathrm{Ci}$ NAD, $1.5 \mu \mathrm{g}$ soybean trypsin inhibitor, $15 \mu \mathrm{g}$ bacitracin, $2 \mu \mathrm{g}$ pertussis toxin, and 10 to $20 \mu \mathrm{g}$ of membrane protein. The incubation was stopped by adding $50 \mu \mathrm{l}$ of stop solution ( $3 \%$ sodium dodecyl sulfate, $42 \%$ glycerol, $15 \%$ 2-mercaptoethanol, $200 \mathrm{~m} M$ Tris- $\mathrm{HCl}, \mathrm{pH} 6.8$ at $20^{\circ} \mathrm{C}$ ) and the mixture was boiled for $5 \mathrm{~min}$. The denatured samples were subjected to sodium dodecyl sulfate polyacrylamide electrophoresis (SDS-PAGE) in $1.5 \mathrm{~mm}$ thick $12.5 \%$ acrylamide gels following Laemmli (1970). The gel was stained with $0.25 \%$ Serva Blue R (Serva Fine Biochemicals, Westbury, New York) in 25\% 2-propanol, $10 \%$ acetic acid, destained, and dried. The dried gels were apposed to Kodak (Rochester, New York) X-Omat AR film. DuPont Cronex Lightning Plus intensifying screens were used. The developed autoradiograms were digitized and quantified with an MCID system (Imaging Research, Inc., St. Catherine, Ontario, Canada).

\section{Immunological quantification of $G$ proteins}

Membranes were diluted to the appropriate protein concentration and electrophoresed in Laemmli sodium dodecyl sulfate mini-gels $(0.75 \mathrm{~mm}$ thick, $4.5 \%$ acrylamide stacking/12.5\% acrylamide resolving) in a BioRad MiniProtean II electrophoresis unit. When using AS/7 antiserum to detect $G_{i \alpha 1}$ and $G_{i \alpha 2}$, we supplemented the resolving gel with $4 M$ urea to enhance separation of these proteins. For routine assays, $10 \mu \mathrm{g}$ samples were diluted in $2 \times$ Laemmli samplc buffer for a final volume of $15 \mu \mathrm{l}$ and heated to $95^{\circ} \mathrm{C}$ for $3 \mathrm{~min}$. Samples of each species were run on each gel.

Proteins were transferred from the gels to nitrocellulose membranes (Schleicher \& Schuell, BA85, $0.45 \mu \mathrm{m}$ ) on a Sartoblot II-S transfer block (Sartorius). Transfer was accomplished in $12 \mathrm{~h}$ at $100 \mathrm{~mA}$ (constant current) using $25 \mathrm{~m} M$ Tris, $150 \mathrm{~m} M$ glycine, $10 \%$ methanol, $\mathrm{pH} 8.3$. The nitrocellulose membrane was stained in $0.2 \%$ Ponceau S (Sigma Chemical Co.) and the polyacrylamide gels were stained with Coomassie Brilliant Blue R (Sigma) to assess completeness of transfer. After destaining in deionized water, the nitrocellulose was blocked for $\mathrm{l} h$ at room temperature with $1 \%$ nonfat dried milk (Carnation) in Tris-buffered saline (TBS: $20 \mathrm{mM}$ Tris $\mathrm{HCl}, 150 \mathrm{mM}$ $\mathrm{NaCl}, \mathrm{pH} 7.5$ and $0.05 \%$ Tween-20). The washed nitrocellulose membrane was incubated overnight at $4^{\circ} \mathrm{C}$ with primary rabbit antisera diluted 1:1000 in 1\% dried milk/ TBS. Following multiple washes in TBS and $1 \%$ dried milk/TBS, the blots were incubated for $2 \mathrm{~h}$ at room temperature with goat anti-rabbit IgG alkaline phosphatase conjugate (Sigma) diluted 1:1000 in 1\% dried milk/TBS. The nitrocellulose was again washed in TBS, and then washed in alkaline phosphatase buffer $(0.1 \mathrm{M}$ Tris- $\mathrm{HCl}$, $0.1 M \mathrm{NaCl}, 2 \mathrm{mM} \mathrm{MgCl}_{2}, 1 \mu M \mathrm{ZnCl}_{2}, 25 \mathrm{~m} M$ diethanolamine, $\mathrm{pH}$ 9.55). Enzyme activity was assayed using $3 \mathrm{mg} / \mathrm{ml}$ nitroblue tetrazolium chloride and $0.17 \mathrm{mg} / \mathrm{ml}$ 5-bromo-4-chloro-3-indolyl phosphate p-toluidine salt (Sigma) in alkaline phosphatase buffer. Color development was stopped after 5 to $10 \mathrm{~min}$ by washing with deionized water. The blots were digitized and quantified using the MCID system.

\section{Data analysis}

Statistical comparisons were made by Student's $t$-test and analysis of variance using Instat (GraphPad, San Diego, California).

\section{Reagents}

[Adenylate- ${ }^{32} \mathrm{P}$ ]-nicotinamide adenine dinucleotide ([ $\left.\left.{ }^{32} \mathrm{P}\right] \mathrm{NAD}, 31.31 \mathrm{Ci} / \mathrm{mmol}\right)$ was from DuPont NEN 


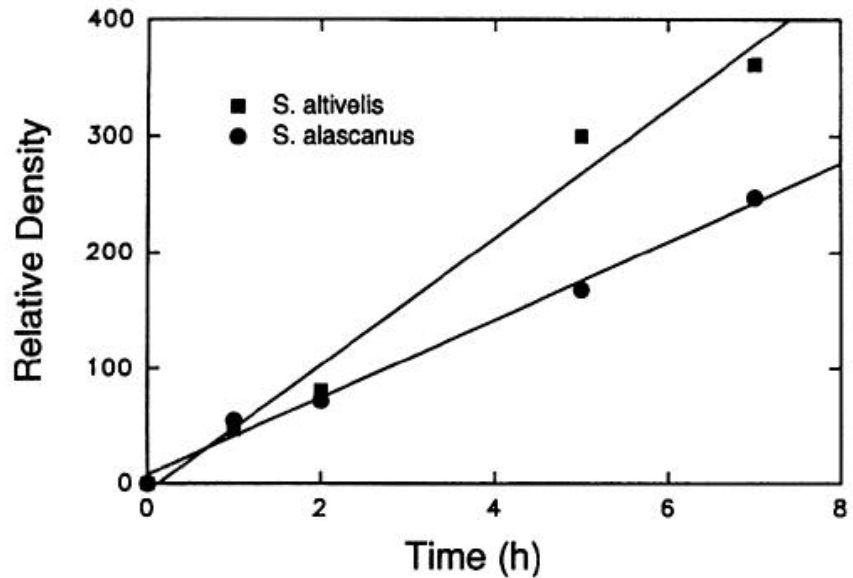

Figure 1. Time course of pertussis toxin-catalyzed $\left[{ }^{32} \mathrm{P}\right] A D P-r i b o-$ sylation of Sebastolobus altivelis (squares) and $S$. alascanus (circles) brain membranes at $5^{\circ} \mathrm{C}$. Preparations were incubated with $2 \mu \mathrm{Ci}\left[{ }^{32} \mathrm{P}\right] \mathrm{NAD}$ and $2 \mu \mathrm{g}$ preactivated pertussis toxin. The samples were denatured and subjected to SDS-PAGE. The dried gels were exposed to $x$-ray film. The relative optical density was determined by densitometric analysis of the autoradiogram. The results are from a single experiment which was replicated twice with similar results.

(Boston, Massachusetts). Pertussis toxin (islet activating protein) was from List Biological Laboratories, Inc. (Campbell, California). Water was processed through a four-bowl Milli-Q purification system (Millipore, Bedford, Massachusetts). Molecular weight standards were from BioRad. The antipeptide antisera obtained from DuPont NEN were $A S / 7$ (recognizes $G_{i \alpha 1}$ and $G_{i \alpha 2}$, Goldsmith $e t$ al., 1987, 1988), EC/2 (recognizes $\mathrm{G}_{\mathrm{i} \alpha 3}$ and $\mathrm{G}_{\mathrm{o} \alpha}$, Simonds et al., 1989) $\mathrm{GC} / 2$ (recognizes $\mathrm{G}_{\mathrm{o} \alpha}$, Spiegel, 1990) and MS/1 (recognizes $\mathrm{G}_{\beta}$, Goldsmith et al., 1988). These antisera had been raised to deduced consensus sequence peptides of the carboxy- and amino-termini of $\mathrm{G}$ protein subunits of mammalian species (e.g., McKenzie et al., 1988; Mumby and Gilman, 1991). Other reagents were purchased from Sigma Chemical Co. (St. Louis, Missouri).

\section{Results}

The time course of pertussis toxin-catalyzed $\left[{ }^{32} \mathrm{P}\right] \mathrm{ADP}-$ ribosylation of brain membranes from $S$. altivelis and $S$. alascanus is depicted in Figure 1. At $5^{\circ} \mathrm{C}$, the labeling of $\mathrm{G}$ protein $\alpha$ subunits was linear for $7 \mathrm{~h}$ in both species.

The pertussis toxin concentration-response relationships in both species were evaluated in a fixed 6-h incubation. Equivalent amounts of $S$. altivelis and $S$. alascanus membrane protein were loaded on SDS-polyacrylamide gels following the $\left[{ }^{32} \mathrm{P}\right] \mathrm{ADP}$-ribosylation reaction. The dependence of $\left[{ }^{32} \mathrm{P}\right] \mathrm{ADP}$-ribosylation on pertussis toxin concentration is shown in the autoradiogram in Figure 2. In brain membranes from both species there was no specific labeling in the absence of pertussis toxin. The extent

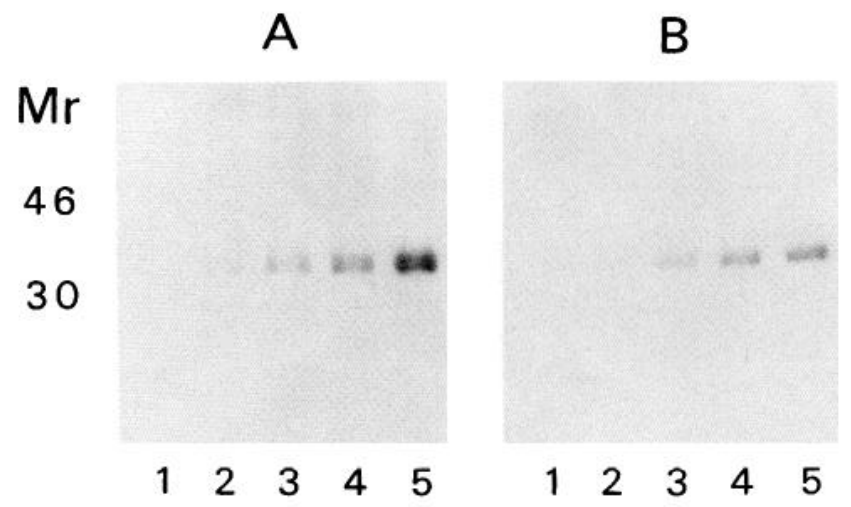

Figure 2. Autoradiogram of pertussis toxin-catalyzed $\left[{ }^{32} \mathrm{P}\right] \mathrm{ADP}-\mathrm{ri}-$ bosylation of Sebastolobus altivelis (A) and S. alascanus (B) brain membranes. Membranes were incubated for $6 \mathrm{~h}$ at $5^{\circ} \mathrm{C}$ with $2 \mu \mathrm{Ci}\left[{ }^{32} \mathrm{P}\right] \mathrm{NAD}$ in the presence of increasing concentrations of pertussis toxin. The concentrations of pertussis toxin used are Lane $1,5 \mathrm{ng} / \mu \mathrm{l}$; Lane $2,10 \mathrm{ng} /$ $\mu \mathrm{l}$; Lane 3, $25 \mathrm{ng} / \mu \mathrm{l}$; Lane 4, $50 \mathrm{ng} / \mu \mathrm{l}$, and Lane $5,100 \mathrm{ng} / \mu \mathrm{l}$. The membranes were subjected to SDS-PAGE and labeled proteins were detected by autoradiography. The results are from a single representative experiment that was repeated three times.

of $\left[{ }^{32} \mathrm{P}\right] A D P-$ ribosylation increased as a function of pertussis toxin concentration $(5-100 \mathrm{ng} / \mu \mathrm{l})$ in both species. The labeling was consistently greater in $S$. altivelis membranes. Proteins of $39 \mathrm{kDa}$ and $41 \mathrm{kDa}$ were radiolabeled in both species. Image analysis of the autoradiograms per-

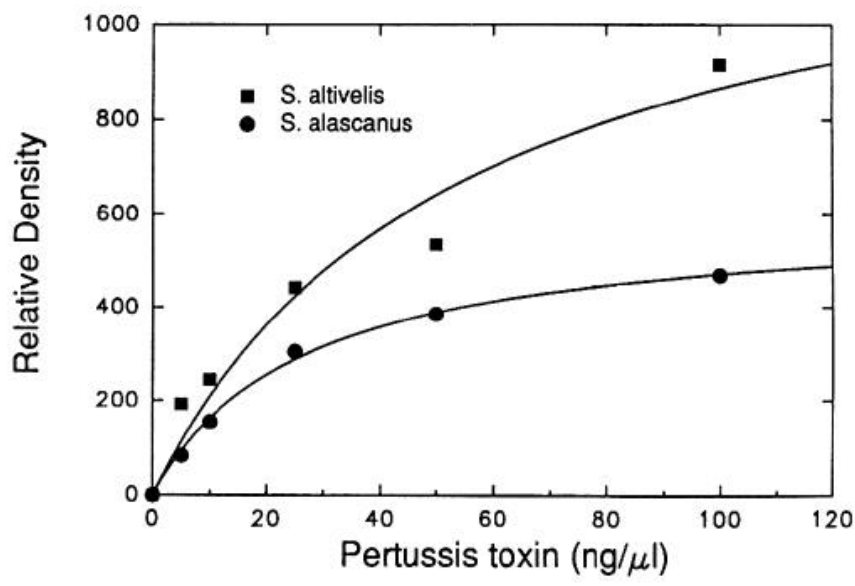

Figure 3. Concentration-response relationship for pertussis toxincatalyzed $\left[{ }^{32} \mathrm{P}\right] \mathrm{ADP}$-ribosylation of Sebastolobus altivelis (squares) and $S$. alascanus (circles) brain membranes for $6 \mathrm{~h}$ at $5^{\circ} \mathrm{C}$. The curves are the best fits to the data using the logistic function: $E=\left(E_{\max }\right) /\left(1+E_{50} /\right.$ [PTX]). $\mathrm{E}$ is the effect in units of relative optical density and $E_{\max }$ is the maximum effect. $\mathrm{EC}_{50}$ is the concentration of pertussis toxin (PTX) which produced $50 \%$ of the maximum effect, and [PTX] is the concentration of pertussis toxin. The maximum extent of [ $\left.{ }^{32} \mathrm{P}\right] \mathrm{ADP}$-ribosylation in $S$. altivelis brain membranes was 2.2 -fold greater than the level of [ $\left.{ }^{32} \mathrm{P}\right] \mathrm{ADP}$ ribosylation in $S$. alascanus membranes. The results depicted represent the fits to pooled data from three separate experiments. The parameter estimates derived from this analysis are shown in Table I. 
Table I

Analysis of pertussis toxin concentration-response relationships in Sebastolobus altivelis and $\mathrm{S}$. alascanus brain membranes

\begin{tabular}{lcr}
\hline \multicolumn{1}{c}{ Species } & Pertussis toxin $\mathrm{EC}_{50}(\mathrm{ng})$ & $\mathrm{E}_{\max }(\mathrm{ROD})$ \\
\hline S. alascanus & $26.7 \pm 3$ & $597 \pm 25$ \\
S. altivelis & $53.5 \pm 27$ & $1329 \pm 325$ \\
\hline
\end{tabular}

$E_{\max }$ units are relative optical density (ROD).

mitted quantification of the relative optical density of each lane. The resultant pertussis toxin concentration-response curves are shown in Figure 3. The maximum level of $\left[{ }^{32} \mathrm{P}\right] \mathrm{ADP}-$-ribosylation is significantly greater in $\mathrm{S}$. altivelis brain membranes than in $S$. alascanus membranes (Fig. 3, Table I). The $\mathrm{EC}_{50}$ values for pertussis toxin in the two species were not significantly different (Table I).

The increase in the extent of pertussis toxin-induced labeling of $\mathrm{G}$ protein $\alpha$ subunits in $S$. altivelis could be due to a greater accessibility of the ribosylation sites of the $G_{i \alpha}$ and $G_{o \alpha}$ substrates, or to elevated quantities of $\mathrm{G}_{\mathrm{i} \alpha}$ and $\mathrm{G}_{\mathrm{\alpha} \alpha}$ or $\mathrm{G}_{\beta \gamma}$. Western immunoblots were employed to quantify the levels of $\mathrm{G}$ protein $\alpha$ and $\beta$ subunits in brain membranes of the two Sebastolobus species. For these studies, another deep-living species, Antimora rostrata, exemplified the pattern and diversity of immunoreactive material in brain membranes from another marine fish family (Moridae). Rat (Rattus rattus) brain membranes were employed as a reference to aid in identifying the immunoreactive material. Equal amounts of membrane protein from each species were loaded on gels and an array of antipeptide antisera were employed to detect $\mathrm{G}_{\mathrm{i} \alpha 1}, \mathrm{G}_{\mathrm{i} \alpha 2}, \mathrm{G}_{\mathrm{i} \alpha 3}, \mathrm{G}_{\mathrm{o} \alpha}$ and the $\beta$ subunit. Standard curves were generated for each antiserum by varying the amount of membrane protein loaded on gels. The inten-
Table II

Quantitation of material in brain membranes of Sebastolobus alascanus and $\mathrm{S}$. altivelis immunoreactive to antibodies directed against $\alpha$ and $\beta$ subunits of $G_{i}$ and $G_{o}$

\begin{tabular}{lcl}
\hline \hline Subunit & S. alascanus & \multicolumn{1}{c}{ S. altivelis } \\
\hline $\mathrm{G}_{\mathrm{i}} \alpha_{1}$ & $1(9)$ & $1.14 \pm 0.29(8)$ \\
$\mathrm{G}_{\mathrm{i}} \alpha_{2}$ & $1(10)$ & $1.09 \pm 0.19(9)$ \\
$\mathrm{G}_{\mathrm{i}} \alpha_{3}$ & $1(12)$ & $1.63 \pm 0.40^{*}(12)$ \\
$\mathrm{G}_{\mathrm{o}} \alpha$ & $1(13)$ & $1.12 \pm 0.28(13)$ \\
$\beta_{36}$ & $1(14)$ & $1.06 \pm 0.10(11)$ \\
\hline
\end{tabular}

The data are standardized to $S$. alascanus. The number of determinations is given in parentheses.

* Value significantly different from the 1.00 value at $P<0.05$.

sity of staining of $G$ protein subunits was within the linear range of immunoreactivity for the results shown. Representative immunoblots for $G_{i \alpha 1}, G_{i \alpha 2}, G_{i \alpha 3}$, and $G_{o \alpha}$ are depicted in Figure 4.

Using antiserum $E C / 2$ to detect $G_{i \alpha 3}$, we observed a single band in brain membranes of the four species. This band from brain membranes of $A$. rostrata and $R$. rattus migrated as an approximately $41 \mathrm{kDa}$ protein. The corresponding protein in both Sebastolobus species had a lesser apparent molecular mass. The intensity of staining of this protein was consistently greater $($ mean $=1.63-$ fold) in $S$. altivelis than in $S$. alascanus brain membranes (Table II). Antiserum EC/2 was raised against the carboxyterminal decapeptide of mammalian transducin- $\alpha$ (Goldsmith et al., 1987) and crossreacts somewhat with both $\mathrm{G}_{\mathrm{o} \alpha}$ and $\mathrm{G}_{\mathrm{i} \alpha \mathrm{l}}$ (Simonds et al., 1989). Because only a single band was identified in each species, these bands are tentatively identified as $\mathrm{G}_{\mathrm{i} \alpha 3}$.

Antiserum $\mathrm{GC} / 2$ was used to detect $\mathrm{G}_{\mathrm{o} \alpha}$. As shown in Figure 4, this antiserum recognized a single band of ap-
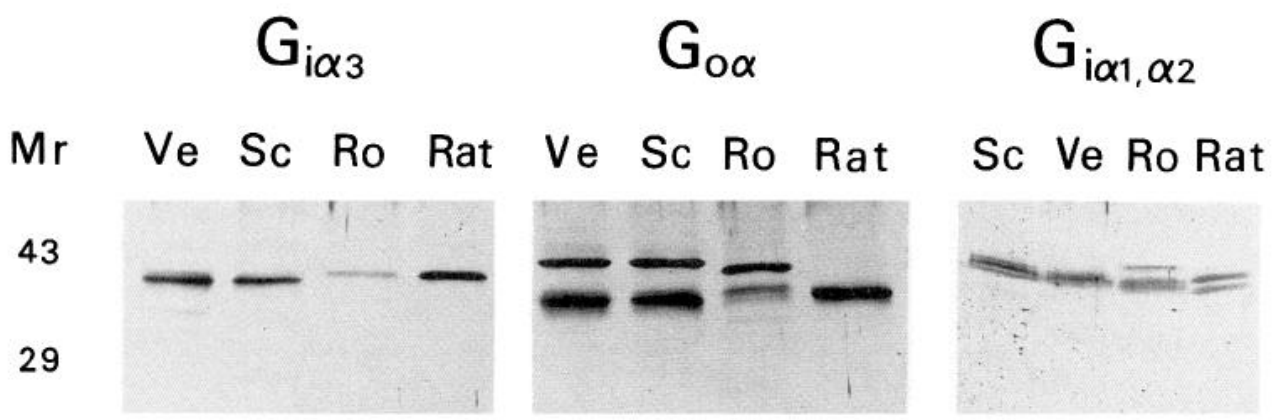

Figure 4. Immunoblots of Sebastolobus altivelis (Ve), S. alascanus (Sc), Antimora rostrata (Ro), and Rattus rattus (Rat) brain membranes obtained with peptide antisera specific for $\mathrm{G}$ protein $\alpha$ subunits. Brain membranes were subjected to SDS-PAGE, and the separated proteins were transferred to nitrocellulose membranes. Immunoblotting was performed with antiserum $E C / 2$, selective for $G_{i \alpha 3}$, antiserum $G C / 2$, selective for $G_{o \alpha}$ and antiserum AS/7 which recognizes $G_{i \alpha 1}$ and $G_{i \alpha 2}$. The positions of molecular weight standards are indicated. 


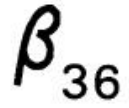

$\mathrm{Mr}$ Ve Sc Ro Rat

43

29

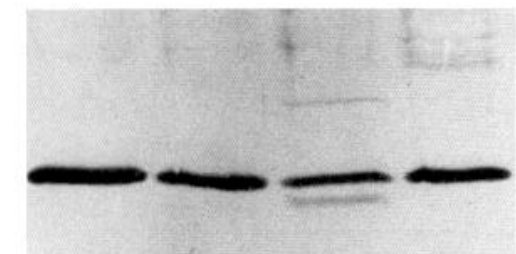

Figure 5. Immunoblots of Sebastolobus altivelis (Ve), S. alascanus $(\mathrm{Sc})$, Antimora rostrata (Ro), and Rattus rattus (Rat) brain membranes obtained using a peptide antiserum (MS/1) which recognizes the $\beta$ subunit $(36 \mathrm{kDa})$ of $\mathrm{G}$ proteins.

proximately $39 \mathrm{kDa}$ in rat brain membranes, but two immunoreactive proteins were detected in all three marine fishes. In addition to a heavily stained band of approximately $39 \mathrm{kDa}$, which likely represents $\mathrm{G}_{\mathrm{o} \alpha}$, brain membranes from the marine teleosts displayed immunoreactive proteins of apparent molecular masses of 41 to $42 \mathrm{kDa}$. There were no significant differences between the two $S e$ bastolobus species in the intensity of immunoreactive bands detected with the antiserum GC/2 (Table II).

The antipeptide antiserum AS/7 was used to identify $\mathrm{G}_{\mathrm{i} \alpha 1}$ and $\mathrm{G}_{\mathrm{i} \alpha 2}$. These $\alpha$ subunits in rat brain were readily resolved in the presence of $4 M$ urea in the running gel (Fig. 4). This doublet was not resolved as well in the three marine fishes, where the band tentatively identified as $\mathrm{G}_{\mathrm{i} \alpha 2}$ migrated somewhat slower than the corresponding protein in rat brain membranes. There were no significant differences in the levels of $\mathrm{G}_{\mathrm{i} \alpha 1}$ or $\mathrm{G}_{\mathrm{i} \alpha 2}$ between the Sebastolobus species (Table II).

Immunoblots of $\mathrm{G}$ protein $\beta$ subunits are depicted in Figure 5 . The antiserum MS/1 was used to quantify the $36 \mathrm{kDa} \beta$ subunits, and the intensity of these bands did not differ significantly between the Sebastolobus species (Table II).

The substrate for the pertussis toxin-catalyzed ADPribosylation reaction is the heterotrimeric holoprotein (Neer et al., 1984; Van Dop et al., 1984), and as a consequence, guanyl nucleotides are capable of modulating the sensitivity of $\mathrm{G}$ proteins to pertussis toxin (e.g., Gierschik, 1992). We therefore compared the guanyl nucleotide regulation of ADP-ribosylation in $S$. altivelis and $S$. alascanus. The aim was to examine the differential susceptibility of the $\mathrm{G}$ protein $\alpha$ subunits to modification by pertussis toxin.
Increasing concentrations of guanosine 5 '-diphosphate (GDP) included in the incubation with pertussis toxin augmented the extent of $\left[{ }^{32} \mathrm{P}\right] \mathrm{ADP}$-ribosylation in $S$. altivelis brain membranes (Fig. 6). Only the highest concentration tested, $1000 \mu M$ GDP, had an effect in S. alascanus brain membranes, and this effect was modest (Fig. 6).

Incubation with the nonhydrolyzable GTP analog guanosine 5'-O-(3-thiotriphosphate) $(\mathrm{GTP} \gamma \mathrm{S})$ effected a marked suppression of $\left.{ }^{32} \mathrm{P}\right]$ ADP-ribosylation in $S$. alascanus brain membranes (Fig. 7). $\left.{ }^{32} \mathrm{P}\right] \mathrm{ADP}$-ribosylation of the $\mathrm{G}$ protein $\alpha$ subunits of $S$. altivelis membranes was relatively insensitive to the effect of GTP $\gamma \mathrm{S}$ (Fig. 7). The concentration-dependent inhibition of pertussis toxincatalyzed ADP-ribosylation produced by GTP $\gamma \mathrm{S}$ in $S$. alascanus brain membranes presumably reflects a dissociation of the $G_{i}$ and $G_{o}$ heterotrimers.

\section{Discussion}

Pertussis toxin catalyzes the incorporation of significantly more $\left[{ }^{32} \mathrm{P}\right] \mathrm{ADP}$ into brain membranes of $S$. altivelis than of $S$. alascanus (Siebenaller et al., 1991; Fig. 2 and 3 , Table I). Although $S$. altivelis brain membranes have

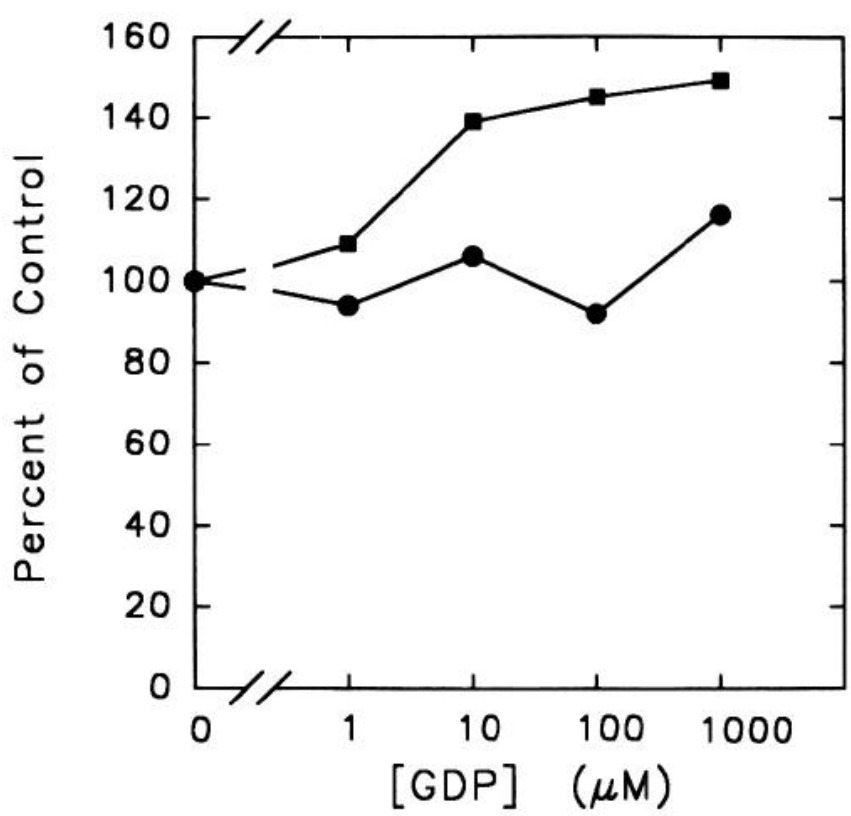

Figure 6. Effects of GDP on pertussis toxin-catalyzed [ $\left.{ }^{32} \mathrm{P}\right] \mathrm{ADP}$ ribosylation of $\mathrm{G}$ protein $\alpha$ subunits in brain membranes of $S$. altivelis (squares) and $S$. alascanus (circles). Membranes were incubated with $2 \mu \mathrm{Ci}\left[{ }^{32} \mathrm{P}\right] N A D$ and $2 \mu \mathrm{g}$ preactivated pertussis toxin in the presence of increasing concentrations of GDP. Incubations were at $5^{\circ} \mathrm{C}$ for $6 \mathrm{~h}$. SDS-PAGE and autoradiography were carried out as described in Materials and Methods. The ordinate values represent the relative optical density of autoradiograms expressed as \% of control value determined in the absence of GDP. The results depicted are derived from a single experiment which was replicated twice with similar results. 


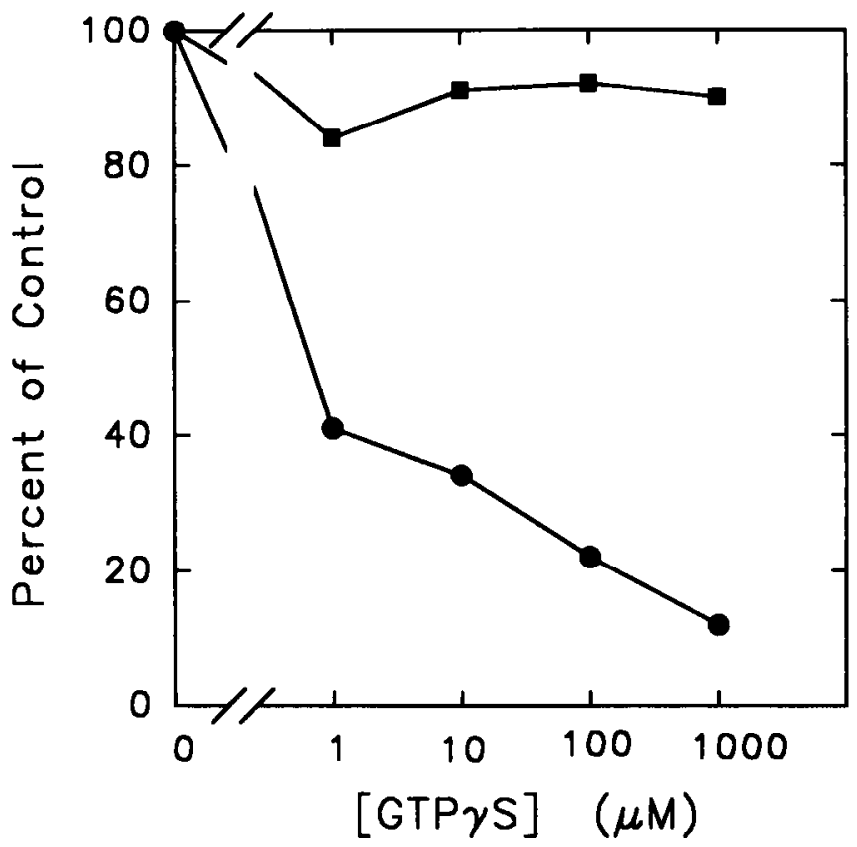

Figure 7. Effects of GTP $\gamma S$ on pertussis toxin-catalyzed $\left[{ }^{32} \mathrm{P}\right] \mathrm{ADP}-$ ribosylation of $\mathrm{G}$ protein $\alpha$ subunits in brain membranes of $S$. altivelis (squares) and $S$. alascanus (circles). The methods and data presentation are as described in the legend to Figure 6.

a $63 \%$ higher level of one subtype of pertussis toxin substrate, $G_{i \alpha 3}$ (Table II), a simple increase in the amount of $\mathrm{G}$ protein substrates cannot adequately explain the differences between the two species. There are also qualitative differences in the pertussis toxin-catalyzed reaction; i.e., the guanyl nucleotides GDP and GTP $\gamma$ S modulate the $\left.{ }^{32} \mathrm{P}\right] A D P-r i b o s y l a t i o n$ reaction differently in the membranes of the two species (Figs. 6, 7). These experiments indicate that $S$. alascanus brain membranes contain lower quantities of one type of pertussis toxin substrate, and that the ribosylation sites of the substrates are less accessible to pertussis toxin.

The differences between the two species in the guanyl nucleotide modulation of ribosylation may relate to the interactions of $G_{i}$ and $G_{0}$ with receptors. The $A_{1}$ adenosine receptors of $S$. alascanus brain membranes are more tightly coupled to $G$ proteins, and a larger fraction exist coupled, than are those of $S$. altivelis (Murray and Siebenaller, 1987). This conclusion is based on the greater agonist affinity of the $A_{1}$ adenosine receptor and the larger fraction of receptors in the high affinity state in $S$. alascanus (Murray and Siebenaller, 1987). The present study suggests that this relatively tighter coupling may be characteristic of other receptors. Tighter receptor-G protein interactions might explain the reduced susceptibility to pertussis toxin-catalyzed ADP-ribosylation in $S$. alascanus membranes; i.e., it would reduce accessibility of the carboxyterminal ADP-ribosylation site to pertussis toxin due to steric hindrance caused by the receptor.
Both the subunit aggregation state of $G_{i}$ and $G_{o}$ and interactions with other membrane components will affect the susceptibility of these $\mathrm{G}$ proteins to $\left[{ }^{32} \mathrm{P}\right] \mathrm{ADP}$-ribosylation (Neer et al., 1984; Van Dop et al., 1984; Panico et al., 1990; van der Ploeg et al., 1992). The carboxyterminal region of the $G$ protein is involved in interactions with receptors (Boege et al., 1991) and may sterically hinder modification of the cysteine that is ADP-ribosylated (West et al., 1985). Because guanyl nucleotides affect the aggregation state and conformation of $G$ proteins, we compared the effects of guanyl nucleotides in modulating pertussis toxin-induced ADP-ribosylation.

GDP augmented the level of ADP-ribosylation produced by pertussis toxin to a greater extent in $S$. altivelis than in $S$. alascanus brain membranes (Fig. 6); only the highest concentration of GDP tested $(1000 \mu M)$ was effective in $S$. alascanus membranes. GDP may enhance $\left[{ }^{32} \mathrm{P}\right] \mathrm{ADP}$-ribosylation by promoting the formation and stabilization of the substrate $\mathrm{G}_{\alpha \beta \gamma}$ holoprotein (Birnbaumer et al., 1990) and by dissociating the $G_{\alpha \beta_{\gamma}}$ holoprotein from unoccupied receptors (Panico et al., 1990; van der Ploeg et al.. 1992). This latter action would facilitate ADPribosylation by relieving the steric hindrance caused by receptor coupling to heterotrimeric $G$ proteins (van der Ploeg et al., 1992). Thus, by promoting the dissociation of the unoccupied receptor- $\mathrm{G}_{\alpha \beta \gamma}$ complex, GDP may expose the carboxyterminal cysteine residue to pertussis toxin. In $S$. alascanus brain membranes, G proteins more tightly coupled to high-affinity forms of receptors would have a reduced affinity for GDP.

In the presence of GTP $\gamma$, the extent of incorporation of the radiolabel into $\mathrm{G}$ protein $\alpha$ subunits of $S$. alascanus brain membrane was markedly suppressed; $S$. altivelis $\mathrm{G}$ protein $\alpha$ subunits were much less sensitive to this inhibitory modulation (Fig. 7). The results with $S$. alascanus membranes are in accordance with the demonstration that GTP $\gamma$ S markedly inhibits pertussis toxin-catalyzed ADPribosylation of a $40 \mathrm{kDa}$ protein in rat glioma membranes (Milligan, 1987). GTP $\gamma$ S promoting the dissociation of $\mathrm{G}_{\mathrm{i}}$ and $\mathrm{G}_{\mathrm{o}}$ protein heterotrimers into $\alpha \cdot \mathrm{GTP} \gamma \mathrm{S}$ and $\beta \gamma$ subunits may underlie this effect, although a GTP $\gamma \mathrm{S}$ induced conformational change in $\mathrm{G}$ proteins has also been reported to inhibit ADP-ribosylation (Mattera et al., 1987; Yi et al., 1991).

Tighter association of receptors and G proteins in $S$. alascanus would result in a larger fraction of coupled receptors. This could promote, relative to uncoupled $G$ proteins, the binding of GTP $\gamma \mathrm{S}$ to the unoccupied guanyl nucleotide binding site, eliciting the dissociation of the $G$ protein subunits, and a resultant decrease in [ $\left.{ }^{32} \mathrm{P}\right] \mathrm{ADP}-$ ribosylation. This would be less likely to occur in $S$. altivelis brain membranes inasmuch as the uncoupled population of $G$ protein heterotrimers would be largely GDP-liganded. The modest GDP-enhancement of ADP- 
ribosylation in $S$. altivelis membranes could result from the stabilization and recruitment of that fraction of $G$ proteins that are either uncoupled or loosely coupled, and unliganded by GDP.

This reasoning is supported by several observations. First, unoccupied receptors can stimulate, albeit weakly, $\mathrm{G}$ protein activation; signaling is a consequence of an agonist-induced increase in the efficacy of $G$ protein-receptor coupling (Birnbaumer et al., 1990; Mukai et al., 1992). Second, the high affinity states of receptors, i.e., $G$ protein-coupled states, can be abolished by the addition of guanyl nucleotides (Mukai et al., 1992). Third, solubilized receptors are often isolated precoupled with $G$ proteins and this coupling can be disrupted by the addition of guanyl nucleotides (Leid et al., 1989).

The coupling of $\mathrm{G}$ proteins and receptors is sensitive to the degree of membrane order (Casadó et al., 1992). In porcine brain cortical membranes, increased membrane viscosity abolishes the high affinity ( $G$ protein-coupled) $A_{1}$ adenosine receptor state (Casadó et al., 1992). In hepatocytes, membrane viscosity influences the lateral movement of components of the glucagon-G protein-adenylyl cyclase complex necessary for signal transduction (Houslay et al., 1980, 1981). The brain membrane phospholipid and fatty acid compositions of the Sebastolobus species are identical, and the different hydrostatic pressures experienced by the species will impose different degrees of membrane order (Siebenaller, 1991). A less efficient coupling of receptors in brain membranes of the deeperliving $S$. altivelis may reflect a requirement for greater conformational flexibility and mobility for elements functioning in the more ordered membrane environment of $S$. altivelis at its in situ pressure. That the $G_{i}$ and $G_{o}$ proteins of $S$. altivelis membranes are better substrates for pertussis toxin-catalyzed [ $\left.{ }^{32} \mathrm{P}\right] \mathrm{ADP}$-ribosylation may reflect this greater conformational flexibility. Based on these considerations, we predict that, in addition to the $A_{1}$ adenosine receptor, other $G$ protein-coupled receptor signaling complexes will be sensitive to pressure perturbation.

The precise homology of the $\mathrm{G}$ protein $\alpha$ subunits in fish membrane to mammalian $\alpha$ subunits cannot be ascertained at present, although comparisons of cloned $\alpha$ subunit genes from a variety of organisms suggest a slow evolution of these genes, as would be expected for proteins with such important biological functions (Yokoyama and Starmer, 1992). The array of $G$ protein subunits identified in three fishes from two families with antisera directed against mammalian consensus peptides supports the evolutionary conservation of these proteins. But the unique protein in fish brain identified with $\mathrm{GC} / 2$ antiserum (Fig. 4) and the altered electrophoretic mobilities of $G_{i \alpha 3}$ in the Sebastolobus species (Fig. 4) suggest that there may be phylogenetic diversity as well. The central role played by
G proteins in transmembrane signaling makes them an important site for adaptation to environmental parameters.

\section{Acknowledgments}

This research was supported by ONR grant N0014-89$\mathrm{J}-1865$ and NSF grant DCB-8710155. We thank the scientific parties on the $\mathrm{R} / \mathrm{V}$ Wecoma cruises, particularly J. M. Willis. Shiptime on the R/V Gyre off the coast of Newfoundland was supported by NSF grant DMB8502857 to Dr. A. F. Riggs. We thank Drs. A. Riggs and R. Noble for their help in obtaining specimens of Antimora rostrata. We thank Patricia Perry, Valerie Caldwell, and Barbara Hettinger-Smith for the Western immunoblots and Ron Bouchard for photographic services.

\section{Literature Cited}

Barinaga, M. 1991. How the nose knows: olfactory receptors cloned. Science 252: 209-210.

Birnbaumer, L. 1992. Receptor-to-effector signaling through $\mathrm{G}$ proteins: Roles for $\beta \gamma$ dimers as well as $\alpha$ subunits. Cell 71: 1069-1072.

Birnbaumer, L., J. Abramowitz, and A. M. Brown. 1990. Receptoreffector coupling by $\mathrm{G}$ proteins. Biochim. Biophys. Acta 1031: 163224.

Boege, F., E. Neumann, and E. J. M. Helmreich. 1991. Structural heterogeneity of membrane receptors and GTP-binding proteins and its functional consequences for signal transduction. Eur. J. Biochem. 199: $1-15$.

Casadó, V., J. Mallol, E. I. Canela, R. Franco, and C. Lluis. 1992. Modulation of adenosine agonist $\left[{ }^{3} \mathrm{H}\right] \mathrm{N}^{6}-(\mathrm{R})$-phenylisopropyladenosine binding to pig brain cortical membranes by changes of membrane fluidity and of medium physicochemical characteristics. Eur. J. Pharmacol. Mol. Pharmacol. 225: 7-14.

Gierschik, P. 1992. ADP-ribosylation of signal-transducing guanine nucleotide-binding proteins by pertussis toxin. Current Topics in Microbiology and Immunology 175: 69-96.

Gilman, A. G. 1987. G proteins: transducers of receptor-generated signals. Ann. Rev. Biochem. 56: 615-649.

Goldsmith, P., P. Gierschik, G. Milligan, C. G. Unson, R. Vinitsky, H. Malech, and A. M. Spiegel. 1987. Antibodies directed against synthetic peptides distinguish between GTP-binding proteins in neutrophil and brain. J. Biol. Chem. 262: 14683-14688.

Goldsmith, P., K. Rossiter, A. Carter, W. Simonds, C. G. Unson, R. Vinitsky, and A. M. Spiegel. 1988. Identification of the GTPbinding protein encoded by $\mathrm{G}_{\mathrm{i} 3}$ complementary DNA. J. Biol. Chem. 263: 6476-6479.

Haedrich, R. L. and N. R. Merrett. 1988. Summary atlas of deepliving demersal fishes in the North Atlantic Basin. J. Nat. His. 22: $1325-1362$.

Houslay, M. D., I. Dipple, and R. F. Elliott. 1980. Guanosine $5^{\prime}$-triphosphate and guanosine $5 '$-[ $\beta \gamma$-imido]triphosphate effect a collision coupling mechanism between the glucagon receptor and catalytic unit of adenylate cyclase. Biochem. $J$. 186: 649-658.

Houslay, M. D., I. Dipple, and L. M. Gordon. 1981. Phenobarbital selectively modulates the glucagon-stimulated activity of adenylate cyclase by depressing the lipid phase separation occurring in the outer half of the bilayer of liver plasma membranes. Biochem. J. 197: 675-681.

Hubbs, C. L. 1926. The supposed intergradation of two species of Sebastolobus (a genus of scorpaenoid fishes) of western America. American Museum Novitates 216: 1-9. 
Katada, T., and M. Ui. 1982. Direct modification of the membrane adenylate cyclase system by islet-activating protein due to ADPribosylation of a membrane protein. Proc. Natl. Acad. Sci. U.S.A. 79: 3129-3133.

Laemmli, U. K. 1970. Cleavage of structural proteins during the asscmbly of the head of bacteriophage T4. Nature 227: 680-685.

Lefkowitz, R. J. 1992. G proteins: the subunit story thickens. Nature 358: 372.

Leid, M., M. I. Schimerlik, and T. F. Murray. 1989. Agonist radioligand interactions with the solubilized porcine atrial $A_{1}$ adenosine receptor. Mol. Pharmacol. 35: 450-457.

Linden, J. 1991. Structure and function of $A_{I}$ adenosine receptors. FASEB J. 5: 2668-2676.

Lowry, O. H., N. J. Rosebrough, A. L. Farr, and R. J. Randall. 1951. Protein measurement with the Folin phenol reagent. J. Biol. Chem. 193: 265-275.

Mattera, R., J. Codina, R. D. Sekura, and L. Birnbaumer. 1987. Guanosine 5'-O-(3-thiotriphosphate) reduces ADP-ribosylation of the inhibitory guanine nucleotide-binding regulatory protein of adenylyl cyclase $\left(\mathrm{N}_{\mathrm{i}}\right)$ by pertussis toxin without causing dissociation of the subunits of $\mathrm{N}_{\mathrm{i}}$ : evidence of existence of heterotrimeric $p t+$ and $p t$ - conformations of $\mathrm{N}_{\mathrm{i}} . J$. Biol. Chem. 262: 11247-11251.

McKenzie, F. R., I. Mullaney, C. G. Unson, A. M. Spiegel, and G. Milligan. 1988. The use of anti-peptide antisera to probe interactions between receptors and guanine nucleotide binding proteins. Biochem. Soc. Trans. 16: 434-437.

Miller, D. J., and R. N. Lea. 1976. Guide to the Coastal Marine Fishes of California, California Department of Fish and Game, Sacramento.

Milligan, G. 1987. Guanine nucleotide regulation of the pertussis and cholera toxin substrates of rat glioma C6 BU1 cells. Biochim. Biophys. Acta 929: 197-202.

Mukai, H., E. Munekata, and T. Higashijima. 1992. G protein antagonists. J. Biol. Chem. 267: 16237-16243.

Mumby, S. M., and A. G. Gilman. 1991. Synthetic peptide antisera with determined specificity for $\mathrm{G}$ protein $\alpha$ or $\beta$ subunits. Methods Enzymol. 195: 215-233.

Murray, T. F., and J. F. Siebenaller. 1987. Comparison of the binding properties of $A_{1}$ adenosine receptors in brain membranes of two congeneric marine fishes living at different depths. J. Comp. Physiol. 157: $267-277$.

Neer, E. J., J. M. Lok, and L. G. Wolf. 1984. Purification and properties of the inhibitory guanine nucleotide regulatory unit of brain adenylate cyclase. J. Biol. Chem. 259: 14222-14229.

Panico, J., J. H. Parkes, and P. A. Liebman. 1990. The effect of GDP on rod outer segment G-protein interactions. J. Biol. Chem. 265: 18922-18927.

van der Ploeg, I., F. E. Parkinson, and B. B. Fredholm. 1992. Effect of pertussis toxin on radioligand binding to rat brain adenosine $A_{1}$ receptors. J. Neurochem. 58: 1221-1229.

Shinitzky, M. 1984. Membrane fluidity and cellular functions. Pp. 151 in Physiology of Membrane Fluidity. Volume I, M. Shinitzky, ed. CRC Press, Boca Raton.
Siebenaller, J. F. 1984a. Pressure-adaptive differences in NAD-dependent dehydrogenases of congeneric marine fishes living at different depths. J. Comp. Physiol. B 154: 443-448.

Siebenaller, J. F. 1984b. Structural comparison of lactate dehydrogenase homologs differing in sensitivity to hydrostatic pressure. Biochim. Biophys. Acta 786: 161-169.

Siebenaller, J. F. 1987. Biochemical adaptation in deep-sea animals. Pp. 34-48 in Current Perspectives in High Pressure Biology, H. W. Jannasch, A. M. Zimmerman and R. E. Marquis, eds. Academic Press, London.

Sicbenaller, J. F. 1991. Pressure as an environmental variablc: magnitude and mechanisms of perturbation. Pp. 323-343 in Biochemistry and Molecular Biology of Fishes, Volume 1, P. W. Hochachka and T. P. Mommsen, eds. Elsevier, Amsterdam.

Siebenaller, J. F., and T. F. Murray. 1990. $A_{1}$ adenosine receptor modulation of adenylyl cyclase of a deep-living teleost fish, Antimora rostrata. Biol. Bull. 178: 65-73.

Siebenaller, J. F., and T. F. Murray. 1993. The effects of hydrostatic pressure on the low- $\mathrm{K}_{\mathrm{m}}$ GTPase in brain membranes from two congeneric marine fishes. J. Comp. Physiol. B (in press).

Siebenaller, J. F., and G. N. Somero. 1978. Pressure-adaptive differences in lactate dehydrogenases of congeneric fishes living at different depths. Science 201: 255-257.

Siebenaller, J. F., and G. N. Somero. 1989. Biochemical adaptation to the deep sea. Rev. Aquatic Sci. 1: 1-25.

Siehenaller, J. F., A. F. Hagar, and T. F. Murray. 1991. The effects of hydrostatic pressure on $A_{1}$ adenosine receptor signal transduction in brain membranes of two congeneric marine fishes. J. Exp. Biol. 159: $23-43$.

Simon, M. I., M. P. Strathmann, and N. Gautam. 1991. Diversity of G proteins in signal transduction. Science 252: 802-808.

Simonds, W. F., P. K. Goldsmith, J. Codina, C. G. Unson, and A. M. Spiegel. 1989. $G_{i 2}$ mediates $\alpha_{2}$-adrenergic inhibition of adenylyl cyclase in platelet membranes: in situ identification with $\mathrm{G}_{\alpha} \mathrm{C}$-terminal antibodies. Proc. Natl. Acad. Sci. U.S.A. 86: 7809-7813.

Spiegel, A. M. 1990 . Antibodies as probes of the structure and function of heterotrimeric GTP-binding proteins. Pp. 207-224 in ADP-ribosylation Toxins and G-proteins, J. Moss and M. Vaughan, eds. American Society of Microbiology.

Van Dop, C., G. Yamanaka, F. Steinberg, R. D. Sekura, C. R. Manclark, L. Stryer, and H. R. Bourne. 1984. ADP-ribosylation of transducin by pertussis toxin blocks the light-stimulated hydrolysis of GTP and cGMP in retinal photoreceptors. J. Biol. Chem. 259: 23-26.

West, R. E., Jr., J. Moss, M. Vaughan, T. Liu and T.-Y. Liu. 1985. Pertussis toxin-catalyzed ADP-ribosylation of transducin: cysteine 347 is the ADP-ribose acceptor site. J. Biol. Chem. 260: $14428-14430$.

Yi, F., B. M. Denker, and E. J. Neer. 1991. Structural and functional studies of cross-linked $\mathrm{G}_{\mathrm{o}}$ protein subunits. J. Biol. Chem. 266: 3900 3906.

Yokoyama, S., and W. T. Starmer. 1992. Phylogeny and evolutionary rates of $\mathrm{G}$ protein $\alpha$ subunit genes. J. Mol. Evol. 35: 230-238. 